\title{
Determinant Factors Affecting Financial Reporting Quality of Regional Hospital Public Service Agency: Evidence from South Jakarta, Indonesia
}

\author{
Arni Karina \\ \{arni.uns.ibs@gmail.com\}, National University, Jakarta, Indonesia.
}

\author{
Andini Dian Pertiwi \\ \{andinidianpertiwi28@gmail.com\}, National University, Jakarta, Indonesia.
}

\section{Syarifuddin}

\{syarif1963@yahoo.com\}, Faculty of Economics and Business, Hasanuddin University, Makassar, Indonesia.

\begin{abstract}
Aini Indrawati
\{ainiindrijawati@gmail.com\}, Faculty of Economics and Business, Hasanuddin University, Makassar, Indonesia.
\end{abstract}

\author{
Anas Iswanto Anwar \\ \{aianwar@fe.unhas.ac.id\}, Faculty of Economics and Business, Hasanuddin University, Makassar, Indonesia.
}

\section{Bambang Subiyanto}

\{bambang.subiyanto@civitas.unas.ac.id\}, National University, Jakarta, Indonesia.

\begin{abstract}
This study aims to investigate the influence of government accounting standards, human resources competence, utilization of information technology toward financial reporting quality in regional government hospital in South Jakarta Province.This study applies explanotary research in which questionnaires and interviews serve as the primary data. The sample of this study is 36 respondents which consist of 7 regional general hospitals as a saturation sampling during the year 2007. The path analysis and using SPSS 23 version to test the hypothesis. The result indicate that government accounting standards, human resources competence and utilization of information technology has positive sign and significant to the financial reporting quality of regional government hospital in South Jakarta Province.
\end{abstract}

Keywords:

Application Of Governmental Accounting Standards, Human Resource Competency, Utilization Of Information Technology, Financial Reporting Quality

Article Received: 18 October 2020, Revised: 3 November 2020, Accepted: 24 December 2020

\section{Introduction}

Good governance system mechanism is one of the benchmarks government succesfull in running a good government. Based on Law No 17 of 2003 concerning State Finances [1], actualizing transparency and accountability in government finances is preparing and presenting accountability reports in the form of financial reporting.Within DKI Jakarta province government area, there are many Regional Work Units (Satuan Kerja Perangkat Daerah/SKPD) and
Regional Apparatus Work Units (Unit Kerja Perangkat Daerah/UKPD ) having status of Regional Public Service Agencies (Badan Layanan Umum Daerah/BLUD ). SKPD/UKPD which applied BLUD financial pattern is given flexibility in managing their finance by implementing sound business practices to improve sustainable services to public, without seeking benefits to advance general welfare and enrich the life of a nation. Sound business practices about BLUDs managerial flexibility are meaningful as 
an implementation of an organizational function based on good management principles in order to give providing quality, sustainable services, and competitive services.

There are several phenomena of irregularities in terms of financial reporting that have occurred in hospitals with BLUD status in Indonesia, including: i) administrative findings in developing of regional government hospitals. DKI Jakarta in 2016 where there were administrative findings that caused state losses amounting to Rp. 9.9 billion, causing the value of asset recording to be irrelevant and inaccurate[2].ii) Purchase of Sumber Waras Hospital land in 2014. There was a price difference purchased by the Provincial Government DKI Jakarta with the price of an agreement between the hospitals. Sumber Waras and PT CKU, which reached 191 billion rupiah. This can result in information and the price basis used to record the value of assets and cash management in financial reporting to be inaccurate, unreliable, and irrelevant [3].iii) Case of Embung Fatimah Hospital, Batam in 20162017. Audit Board Of Republic Of Indonesia (Badan Pemeriksa Keuangan /BPK ) found a number of violations including debt payments not recorded on the balance sheet, debt payments to employees that have not been paid, debt bills to third parties that are not recorded on the balance sheet, procurement of office stationery expenditures that are not in accordance with regulations, accompanying activities to prepare financial statements that are not appropriate, etc.[4] Note from BPK in the 2017 DKI Jakarta Government Report On Government Finances (Laporan Keuangan Pemerintah Daerah / LKPD) audit sampling states that there were still findings related to the lack of optimal use of information technology for asset management and logistics/inventory management in regional public hospitals,therefore can ultimately affected quality of financial reporting.(Source: Internal Report on Audit Findings on Inventory and Assets Audit Sampling of RSUD in the 2017 DKI Jakarta Provincial Government.)[5]
Regional General Hospital (Rumah Sakit Umum Daerah /RSUD) is UKPD that applies BLUD financial management pattern. Implementation of financial management accountability of RSUD is conveyed through financial reporting and performance reports to the Head of the Health Department (Kepala Dinas Kesehatan). The adoption of Government Accounting Standards as a whole in 2015 requires local governments to prepare accrual-based financial statements including regional public service bodies as accounting entities and reporting entities preparing accrual-based financial statements Minister Of Finance Regulation (Peraturan Menteri Keuangan/PMK No 270/PMK.05/2014). [6]Quality of financial reporting is determined from whether it is prepared by established Government Accounting Standards. Research on the influence of the application of government accounting standards was conducted by Nikke Yusnita Mahardini and Ade Miranti The Impact of Implementing Government Accounting Standards and Human Resources Competence on Quality of 2015 Banten Provincial Government's Financial Statements [7]; Pujanira, Putriasri ,The influence of human resource competence, the application of government accounting standards, and the application of regional financial accounting systems on the quality of the DIY local government financial reports [8]where results of this study showed that the application of government accounting standards had a positive and significant effect on the quality of government financial statements area.

The purpose of this study is to analyze and describe application of governmental accounting standards, human resources competencies, and use of information technology effected to financial reporting quality status as a regional public services agency. This status applied BLUD financial pattern that given flexibility in managing their finance by implementing sound business practices to improve sustainable services to public, without seeking benefits to advance general welfare and enrich the life of a nation. 


\section{Research Methodology}

The type of data used in this study is primary data. Primary data obtained by researchers directly from respondents were Head of Finance, Head of Accounting and Reporting, Treasurer of Expenditures, and staff at the financial units in hospitals that apply the BLUD financial management patterns in the South Jakarta area through distributing research questionnaires. The questionnaire was used to obtain data on the quality of financial reporting, the application of government accounting standards, human resource competencies and the use of information technology.
There were seven hospitals as a subject of this research; 1) Jagakarsa Regional Hospital, 2) Jatipadang Regional Hospital, 3) Pasar Minggu Regional Hospital, 4) Tebet Regional Hospital, 5) Mampang Prapatan Regional Hospital, 6) Pesanggarahan Regional Hospital, 7) Kebayoran Baru Regional Hospital.Population in this study were all employees of the Financial Section of RSUD who applied the BLUD financial management pattern in the South Jakarta area. The valid population was 36 people, and as a sampling technique in this study was carried out using saturated sampling.

According to explaination above, the model of this study can be drawn in figure 1 .

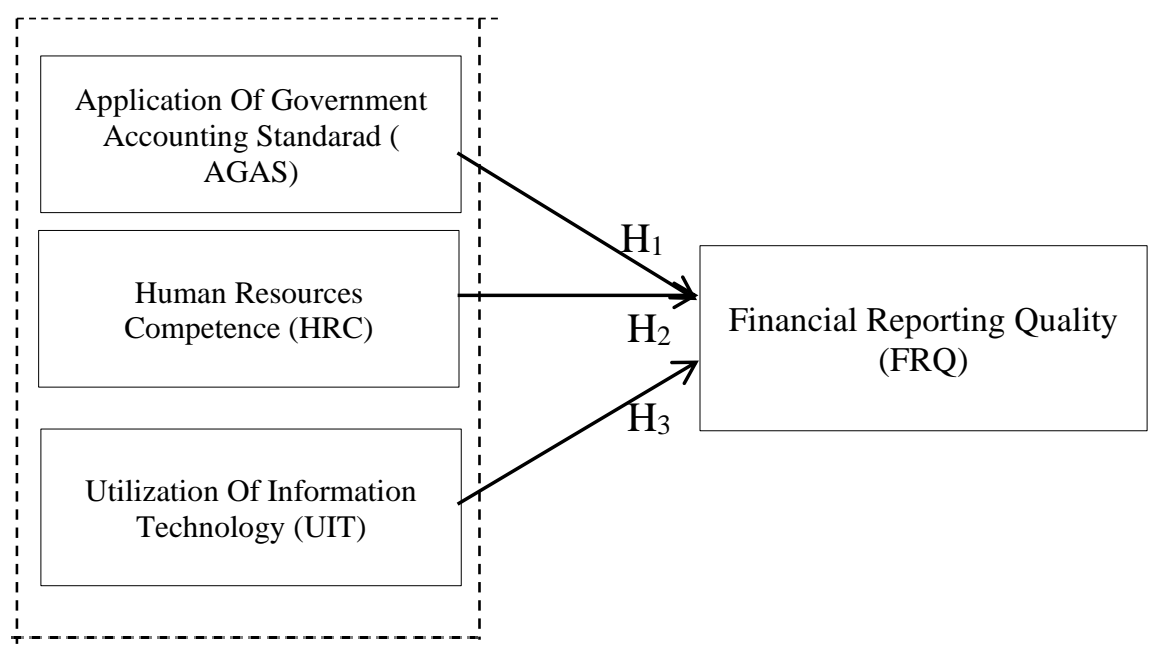

Fig. 1. Hypothesis Model

\section{Validity Test and Reliability Test}

Resulate of validity tes showes all AGAS,HRC, UIT, and FRQ variables show significant results and show $\mathrm{r}$ count $>\mathrm{r}$ table, whrere all correlation coefisiens are more than $\mathrm{R}$ tabel 0,329 ( $\mathrm{R}$ tabel is calulcated according to total samples) It can be concluded that all statement items are declared valid.

Anthoer test is reliability test. According to the SPSS proces of data, Cronbach's Alpha of AGAS is 0,769 , HRC is 0,775 , UIT is 0,838 , and FRQ is 0,898 , these means all variables is greater than 0.70 so that it can be concluded that data all declared to be reliable and can be trusted as a variable measurement tool.

\section{Normality Test}

Based on results of processed by SPSS, the Asymp.Sig of AGAS is 0,200 , HRC is 0,77 , UIT is 0,065 , and FRQ is 0,86. All varibales have Asymp.Sig greter than 0,005 , these means the data in normal distribution.

\section{Multicolinearity Test}

Based on test results, VIF of AGAS is 1,722, HRC is 2,405, and UIT is 1,979. VIF of all variables in range $>0,10$ and $<10$, it means all 
independent variables are no symptoms of multicollinearity between independent variables.

\section{Heteroscadeticity Test}

Scatterplot image shows that the points spread randomly, scattered both above and below zero on the $\mathrm{Y}$ axis and do not form a specific clear pattern. Therefore, the regression model is said not experience of heteroscedasticity. The scatterplot image is showed below:

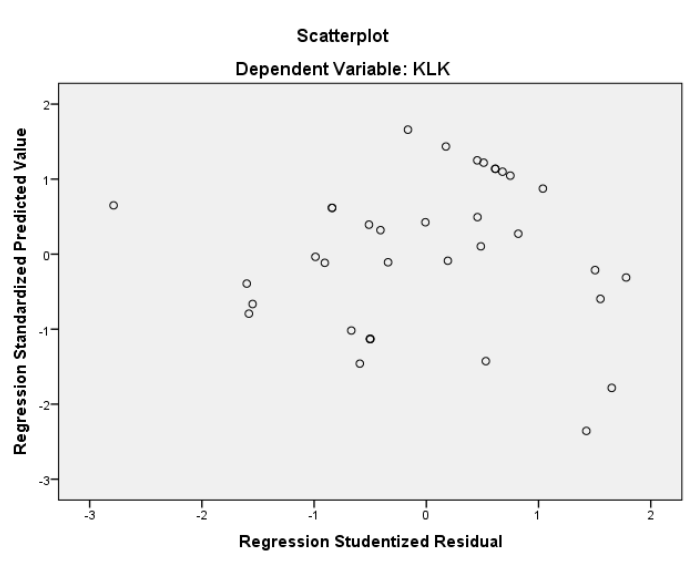

Fig. 2. Heteroscadesticity Test

3 Result and Discussion

Multiple Linear Regression Method

Table 1. Multiple Linear Regression Model

\section{Coefficients $^{\mathbf{a}}$}

\begin{tabular}{|c|c|c|c|c|c|c|c|}
\hline \multirow[b]{2}{*}{ Model } & \multicolumn{2}{|c|}{$\begin{array}{c}\text { Unstandardized } \\
\text { Coefficients }\end{array}$} & \multirow{2}{*}{$\begin{array}{c}\text { Standardi } \\
\text { zed } \\
\text { Coefficie } \\
\text { nts }\end{array}$} & \multirow[b]{2}{*}{$\mathrm{t}$} & \multirow[b]{2}{*}{ Sig. } & \multicolumn{2}{|c|}{$\begin{array}{c}\text { Collinearity } \\
\text { Statistics }\end{array}$} \\
\hline & B & $\begin{array}{l}\text { Std. } \\
\text { Error }\end{array}$ & & & & $\begin{array}{c}\text { Toleran } \\
\text { ce }\end{array}$ & VIF \\
\hline $\begin{array}{l}1 \text { (Constan } \\
\text { t) }\end{array}$ & 2,145 & 4,115 & & ,521 & ,606 & & \\
\hline AGAS & ,297 &, 117 & ,329 & 2,547 & ,016 & ,581 & $\begin{array}{l}1,72 \\
2\end{array}$ \\
\hline HRC & ,435 & ,189 & ,352 & 2,306 &, 028 & ,416 & $\begin{array}{l}2,40 \\
5\end{array}$ \\
\hline UIT &, 351 &, 173 & ,280 & 2,046 &, 041 & ,505 & $\begin{array}{l}1,97 \\
9\end{array}$ \\
\hline
\end{tabular}

Sources: SPSS

These results interpret that all independent variables in this study have a positive influence on the quality of financial reporting. The adoption of improved government accounting standards, 
improved human resource competencies, and optimization use of information technology will have a direct impact on quality of financial reporting.

\section{$Y=2,145+0,297 \times 1+0,435 \times 2+0,351 \times 3+e$}

\section{Determination Coefficient Test}

Table 2. Determination Coefficient Test

\begin{tabular}{l} 
Model Summary \\
\hline
\end{tabular}

a. Predictors: (Constant), AGAS, HRC, UIT

b. Dependent Variable: FRQ

\section{Statistical Test $\mathbf{t}$}

Table 3. Statistical Test $\mathrm{t}$

\begin{tabular}{|c|c|c|c|c|c|c|}
\hline \multirow{2}{*}{\multicolumn{2}{|c|}{ Model }} & \multicolumn{2}{|c|}{ Unstandardized Coefficients } & \multirow{2}{*}{\begin{tabular}{|l|}
$\begin{array}{l}\text { Standardized } \\
\text { Coefficients }\end{array}$ \\
Beta
\end{tabular}} & \multirow[b]{2}{*}{$\mathrm{t}$} & \multirow[b]{2}{*}{ Sig. } \\
\hline & & B & Std. Error & & & \\
\hline \multirow[t]{4}{*}{1} & (Constant) & 2,145 & 4,115 & & ,521 &, 606 \\
\hline & AGAS & ,297 &, 117 &, 329 & 2,547 &, 016 \\
\hline & HRC & ,435 &, 189 &, 352 & 2,306 &, 028 \\
\hline & UIT &, 351 &, 173 &, 280 & 2,046 &, 041 \\
\hline
\end{tabular}

Based on the table above shows that the R-value of 0.831 , which means the relationship of independent variables $(\mathrm{X})$, namely the application of government accounting standards (AGAS), human resource competencies (HRC), and the use of information technology (UIT) to the quality of financial reporting (FRQ) has a relationship of $83.10 \%$ or it can be said that the relationship is very strong (range 0800-1000 is a very strong category). The coefficient of determination (R2) is 0.691 which means it is a combination of the application of government accounting standards 
(AGAS), human resource competencies (HRC), and the use of information technology (UIT) able to explain the dependent variable (FRQ), namely the quality of financial reporting that is equal to $69.10 \%$, the remaining $30.90 \%$ is explained by other variables not examined in this study such as the effectiveness of internal controls, organizational commitment, understanding of regulations, management capabilities and so on.

Based on table above, it can be seen the effect of each independent variable on the dependent variable as follows:

1) Variable implementation of government accounting standards (AGAS) has $t$ count of 2.547 which means $t$ count $>t$ table (2.547> 2.036) and a significance level of AGAS <0.05 which is equal to 0.016 . These results indicate that the application of government accounting standards has a positive and significant effect on quality of financial reporting. Therefore, H1 is accepted, namely the application of government accounting standards and a significant positive effect on the quality of financial reporting.

2) Human resource competency variable (HRC) has $\mathrm{t}$ count value of 2.306 which means $\mathrm{t}$ count> $t$ table (2.306> 2.036) and a significance level of HRC $<0.05$ that is equal to 0.028. These results indicate that human resource competence has positive and significant effect on quality of financial reporting. Therefore, $\mathrm{H} 2$ is accepted, that is, human resource competency has positive and significant effect on quality of financial reporting.

3) Variable utilization of information technology (UIT) has $\mathrm{t}$ count of 2.046 which means $\mathrm{t}$ count $>t$ table (2.046> 2.036) and significance level of UIT $<0.05$ that is equal to 0.041 . These results indicate that use of information technology has a positive and significant effect on quality of financial reporting. Therefore, $\mathrm{H} 3$ is accepted, namely use of information technology and has a significant positive effect on quality of financial reporting.

\section{Conclusion}

The limitations in this study are not all of information gathered from stakeholders who have interest in financial reporting in different way such as Health Office (Dinas Kesehatan), Regional Financial Management Board (Badan Pengelola Keuangan Daerah), Supervisory Board (Dewan Pengawas), Inspectorate (Inspektorat), and etc. In case of whether they assed quality of BLUD financial reports can be more objective and fairer. In addition, stakeholders from higher institutions have higher competence in examining, assessing and overseeing quality of financial statements.

Based on concept of agency theory [9], it was also explained that agent must be responsible to owner in the form of financial reporting with the result that quality of financial reporting better shows that financial governance is better too, so it can create a sense of public trust and can improve the performance of government. Application of government accounting standards has positive and significant effect on quality of financial reporting. Generally Accepted Government Accounting Principles has been applied even though there are still hospitals that are not yet optimal. As for results, implementation of government accounting standards that are not optimal in hospitals shows that BLUD financial management patterns due to lack of internal supervision conducted from direct high level, differences in interpretation and understanding accounting techniques of applying government accounting standards due to $\mathrm{HR}$ placement (the right man on the right place) is not right, and also human resources rotation take place in a fast way, causes obstacles in optimizing applying government accounting standards. Based on Presidential Instruction No. 4 of 2011[10] concerning Acceleration of Improvement Financial Accountability, in order to supervise and 
continue foster hospitals that implement BLUD financial management pattern in order to implement Government Accounting Standards (Standar Akuntansi Pemerintahan/SAP) properly and correctly, regular and periodic monitoring and inspection is carried out.Supervision and inspection are also carried out by the Internal Control Unit (Satuan Pengendalian Internal/SPI) institutions, Supervisory Boards (Dewan Pengawas), accounting supervisors from Regional Financial Management Agency (Badan Pengelola Keuangan Daerah/BPKD), and Inspectorate according to Minister of Finance Regulation (Peraturan Menteri Keuangan/PMK 200/PMK.05/2017)[11] about Public Service Agency Internal Control System.

Improving of $\mathrm{HR}$ competencies in finance field, especially for staff who do not have background in accounting education, it is facilitated to attend competency training in finance. Training supposed not only related to practical expertise but was also supported by ability to understand new laws and regulations [12] (Purba, 2017). This training is expected to be able reducing competency gap in existing human resources hospitals applying financial management patterns of BLUD. HR who works in financial field of RSUD that implements BLUD financial management pattern must be trained every year and must obtain certification of competence in accordance with their respective work responsibilities. Training is about preparation of accrual-based financial reporting and training of government accounting standards (SAP) held by Indonesian Institute of Accountants (Ikatan Akuntan Indonesia/IAI), and Development Agency of Human Resources (Badan Pengembangan Sumber Daya Manusia/BPSDM).Employees who have passed training and exam will receive a certificate of competence recognition according to type of education and training that has been attended. In addition, BPKD accounting advisers routinely upgrade and refresh knowledge and review latest financial regulations every 3 (three) months by conducting socialization.

The last, general financial statements should follow the Government Regulation (Peraturan Pemerintah) Number 65 year 2010[13] concerning Regional Financial Information Systems following implementing development process about good governance principle, it is required to develop and utilize advances in financial information technology to public services .The application must be able to integrate data and information beginning patient are registered until patient discharged from hospital. This matter result in financial transactions that occur from patient services can be presented accurately in a real time. During the industry 4.0 RSUD that implemented BLUD financial management pattern, that must be adjusted to technological developments in order to be able published quality financial information. Utilization of information technology in hospitals that implement BLUD financial management patterns has been well supported by good and sophisticated hardware and software facilities, by using integrated applications Regional Financial Management Information System (Sistem Informasi Pengelolaan Keuangan Daerah/SIPKD); Local Tax Information System (Sistem Informasi Pajak Daerah/SIMPAD); Asset Information Electronic System (Sistem Informasi Elektronik Informasi Asset/SIERA) that have been provided by Regional Financial Management Agency (Badan Pengelola Keuangan Daerah/BPKD) and the Office of Communication and Information (Diskominfo) DKI Jakarta Provincial Government. Use of information technology has a very positive effect on quality of financial reporting because it minimize human error, more accurate, reliable, relevant, trustworthy and able to present data in real time.[14] (Santoso, 2016) In addition, by utilizing information technology, data of financial transaction can be stored in databases and servers with the result that data security is more secure. It helps management to be able to make decisions more quickly because financial 
reporting information can meet the quality aspects are reliable, relevant, trustworthy, and understandable.

\section{References}

[1] Undang-Undang Nomor 17 Tahun 2003 tentang Keuangan Negara

[2] www.poskotanews.com downloads on August 292019

[3] www.tempo.com downloads on August 29 2019

[4] www.jawapos.com download on August 292019

[5] Internal Report on Audit Findings on Inventory and Assets Audit Sampling of RSUD in the 2017 DKI Jakarta Provincial Government 2017

[6] Peraturan Menteri Keuangan Nomor 270/PMK.05/2014 tentang Standar Akuntansi Pemerintahan Berbasis Akrual

[7] Nikke Yusnita Mahardini, Ade Miranti : The Impact of Implementing Government Accounting Standards and Human Resources Competence on the Quality of the 2015 Banten Provincial Government's Financial, Jurnal Akuntansi, Vol 5 No. 1 Januari 2018

[8] Pujanira, Putriasri, The influence of human resource competence, the application of government accounting standards, and the application of regional financial accounting systems on the quality of the DIY local government financial reports.Universitas Negeri Yogyakarta.2017

[9] Jansen, M.C. and William, H .M, 1976. Theory of the Firm: Managerial Behavior, Agency Cost and Ownership Structure, Journal of Financial Economics
[10] Instruksi Presiden No 4 Tahun 2011 tentang Percepatan Peningkatan Akuntabilitas Keuangan

[11] Peraturan Menteri Keuangan/PMK 200 /PMK.05/2017 Sistem Pengendalian Internal Badan Layanan Umum

[12] Purba, Muhammad Hanif. Pengaruh Penerapan Standar Akuntansi Pemerintahan Berbasis Akrual, Kebijakan Akuntansi, Pemanfaatan Teknologi Informasi, Dan Kompetensi Sumber Daya Manusia Terhadap Kualitas Laporan Keuangan Pemerintah Daerah Kabupaten Deli Serdang. Universitas Sumatera Utara 2017

[13] Peraturan Pemerintah (PP) No 65 Tahun 2010 tentang Sistem Informasi Keuangan Daerah

[14] Santoso, Puji. Effects of the Application of Government Accounting Standards, Government Internal Control Systems, Human Resources Competence and Utilization of Financial Information Technology for Regional Governments in Lampung Province. Universitas Lampung (2016) 